\title{
Effect of Nitrous Oxide Anaesthesia on Endotracheal Cuff Pressure
}

\author{
Anestezide Azotprotoksit Kullanımının Endotrakeal Kaf Basıncına Etkisi \\ Özlem Koşar, Öznur Şen*, Mehmet Toptaş* ${ }^{*}$ Gamze Mısırlığlu**, Nurdan Aydın*, Emel \\ Koçer Gür*, Tarık Umutoğlu***
}

Sivas Suşehri State Hospital, Clinic of Anesthesiology and Reanimation Sivas, Turkey

${ }^{*}$ Haseki Training and Research Hospital, Clinic of Anesthesiology, Istanbul, Turkey

${ }^{* *}$ Gebze Fatih State Hospital, Clinic of Anesthesiology, Istanbul, Turkey

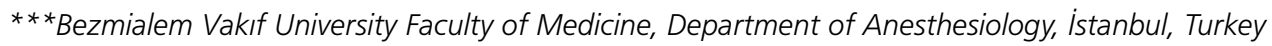

\section{Abstract}

Aim: When $\mathrm{N}_{2} \mathrm{O}$ is used for general anaesthesia, it diffuses into the air-filled endotracheal cuff causing the cuff pressure to rise by over inflating the cuff, which results in tracheal damage. This study aimed to estimate changes in the endotracheal-cuff pressure with time during oxygen-air- and oxygen- $\mathrm{N}_{2} \mathrm{O}$-induced anaesthesia and to determine its sore throat and hoarseness incidence.

Methods: Fifty patients with American Society of Anesthesiologists physical status 1-2, aged 18-60 years were icluded to our study. Orotracheal intubation was performed using polyvinyl chloride high volume-low pressure endotracheal tubes. The AIR group 40\% $\mathrm{O}_{2} / 60 \%$ air and $\mathrm{N}_{2} \mathrm{O}$ group $40 \% \mathrm{O}_{2} / 60 \% \mathrm{~N}_{2} \mathrm{O}$ was used. The endotracheal cuff pressure at 5, 10, 15, 20 minutes immediately after intubation and at 10-minute intervals were recorded. When the cuff pressure reached $45 \mathrm{~cm} \mathrm{H}_{2} \mathrm{O}$, was attenuated to $25-30-\mathrm{cm} \mathrm{H}_{2} \mathrm{O}$. At the post operative first and the 24th hour, the patients were queried for sore throat and hoarseness.

Results: The $\mathrm{N}_{2} \mathrm{O}$-group cuff pressure rose from the fifth minute onwards. Also, the $\mathrm{N}_{2} \mathrm{O}$ group had a higher incidence of sore throat and hoarseness.

Conclusion: $\mathrm{N}_{2} \mathrm{O}$ results in elevated cuff pressure and tracheal morbidities. Cuff-pressure should be routinely monitored during anaesthesia using $\mathrm{N}_{2} \mathrm{O}$.

Keywords: General anaesthesia, nitrous oxide, tracheal intubation, cuff pressure, throat ache, tracheal morbidities
Amaç: Genel anestezide $\mathrm{N}_{2} \mathrm{O}$ kullanıldığında, hava dolu endotrakeal kaf içine diffüze olup, kanın basıncını arttırarak trakeal hasara neden olabilir. Çalışmamızda; oksijen-azotprotoksit ile oksijen-hava kullanımının, endotrakeal kaf basıncı, postoperatif boğaz ağrısı ve ses kısıklığına etkilerinin araştıııması amaçlandı.

Yöntemler: Alt batın operasyonu geçirecek Amerikan Anestezi Derneği 1-2 grubu, 18-60 yaş arası 50 olgu çalışmaya dahil edildi. Anestezi indüksiyonundan sonra oratrakeal entübasyon polivinilklorürden yapılmış, yüksek-volüm, düşük-basınçlı, endotrakeal tüpler ile gerçekleştirildi. Azotprotoksit grubu (grup $\mathrm{N}_{2} \mathrm{O}$ ) \%40 02/\%60 $\mathrm{N}_{2} \mathrm{O}$, hava grubuna (grup AiR) \%40 $\mathrm{O}_{2} / \% 60$ hava olacak şekilde anestezi idamesi sağlandı. Endotrakeal kaf basınc entübasyondan hemen sonraki 5, 10, 15, ve 20. dakikada ve daha sonra 10 dakikalık aralarla

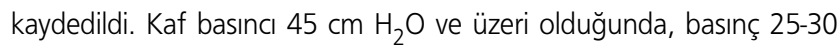
$\mathrm{cm} \mathrm{H}_{2} \mathrm{O}$ ve üzeri olduğunda, basınç 2. saat ve 24 saatte boğaz ağrısının olup olmadığı sorgulandı.

Bulgular: Kaf basınçları karşılaştırıldığında, azotprotoksit grubunda beşinci dakikadan itibaren kaf basınçları giderek yüksek bulunmasına rağmen, hava grubunda basınçlarda anlamlı bir değişiklik görülmedi. Ayrıca azotprotoksit grubunda boğaz ağrısı ve ses kısıklığı daha fazla görüldü.

Sonuç: Genel anestezi sırasında uygulanan azotprotoksit, yüksek kaf basınçlarına ve buna bağlı komplikasyonlara neden olabilmektedir. Bu nedenle azotprotoksit anestezi sırasında kaf basınc rutin olarak monitörize edilmelidir.

Anahtar Sözcükler: Genel anestezi, nitröz oksit, endotrakeal tüp kaf basıncı, boğaz ağrısı, ses kısıklığı
Address for Correspondence/Yazışma Adresi: Öznur Şen

Haseki Training and Research Hospital, Clinic of Anesthesiology, İstanbul, Turkey Phone: +90 2125294400 E-mail: senoznur@gmail.com

Received/Geliş Tarihi: 06 March 2016 Accepted/Kabul Tarihi: 28 June 2016
${ }^{\circ}$ Copyright 2017 by The Medical Bulletin of Haseki Training and Research Hospital
The Medical Bulletin of Haseki published by Galenos Yayınevi. ๑Telif Hakkı 2017 Haseki Eğitim ve Araştırma Hastanesi Haseki Tıp Bülteni, Galenos Yayınevi tarafından basıımıştır. 


\section{Introduction}

Intubation process during anaesthesia is essential for maintaining the patent airway, control of the airway and respiration, airway control during the resuscitation procedure, reduction of the respiratory effort, dead spaces and aspiration risk, and removal of the the equipment from proximity of the surgical team facilitating their activity. Tracheal intubation is the fundamental step in controlling the airways during general anaesthesia (1).

To prevent air escape, cuffed endotracheal tubes are widely preferred in adult patients.

Endotracheal tube (ETT) cuff ensures formation of positive pressure in the airway by preventing air escape during ventilation and prevents aspiration of the pharyngeal contents (1). ETT cuffs are made of polyvinyl chloride (PVC). During general anaesthesia, $\mathrm{N}_{2} \mathrm{O}$ penetrates the inflated cuff. Cuffs made of materials including rubber are more permeable to $\mathrm{N}_{2} \mathrm{O}$ compared to those made of PVC $(2,3)$. When the cuff pressure exceeds $40 \mathrm{~cm} \mathrm{H}_{2} \mathrm{O}$, capillary blood flow is impeded which can cause damage to tracheal structures. If, on the other hand, cuff pressure falls below $25 \mathrm{~cm} \mathrm{H}_{2} \mathrm{O}$, aspiration risk arises (4).

Reported incidence of sore throat after general anaesthesia with endotracheal intubation varies between $14.4 \%$ and $50 \%$, making up the most frequent complication of the intubation process (5). This complaint has been ascribed to the mechanical pressure of the tube, high cuff pressure and ventilation with dry air (4). Other frequently observed complications include hoarseness and dysphagia; and when intubation time is prolonged, tracheal stenosis and tracheomalacia may also occur $(5,6)$. In order to avoid these complications, proper ETT cuff inflation should be obtained for suitable pressure which can be easily and accurately measured with aneroid manometers; but, these gauges are not widely used in Turkey (7).

Our study aimed to monitor and compare the recorded variations of cuff pressure during anaesthesia with oxygen and $\mathrm{N}_{2} \mathrm{O}$ mixture and with oxygen and air mixture using high volume-low pressure ETT cuffs; and to evaluate the effects of these variations on the haemodynamic parameters of blood pressure (BP), mean arterial pressure $(\mathrm{MAP}), \mathrm{SPO}_{2}$, peak heart rate (PHR) and post-operative damage to tracheal structures by checking hoarseness and sore throat.

\section{Methods}

This study was carried out after obtaining the approval of the ethics committee of Haseki Training and Research Hospital (Istanbul) as well as the informed consent of patients included in the study. Our patients, known to have American Society of Anesthesiologists (ASA) physical status 1-2, aged between 18 and 65 years, were scheduled for elective lower abdominal surgery. After entry into the operation room, the patients were given premedication consisting of $0.03 \mathrm{mg} / \mathrm{kg}$ midazolam. HR, systolic $B$, mean $\mathrm{BP}(\mathrm{MBP})$, diastolic $\mathrm{BP}$, and peripheral oxygen $\mathrm{SpO}_{2}$ were monitored. Anaesthesia was induced by a combination of $7 \mathrm{mg} / \mathrm{kg}$ pentothal sodium, $1-2 \mu \mathrm{g} / \mathrm{kg}$ fentanyl citrate and $0.6 \mathrm{mg} / \mathrm{kg}$ rocuronium bromide. After achieving muscular relaxation, intubation was carried out using high-volume low-pressure siliconized PVC ETTs. Patients who could not be intubated at the first attempt were excluded from the study. ETT cuff was inflated with air with adjustments by palpating the pilot balloon, and then, the pilot balloon and the pressure manometer (Rüsch EndoTest) were connected, and the pressure measurements were recorded. The initial cuff pressure exceeding $35 \mathrm{~cm} \mathrm{H}_{2} \mathrm{O}$ was reduced by means of the manometer to $25-30 \mathrm{~cm}$ $\mathrm{H}_{2} \mathrm{O}$ without air escape.

The patients were randomly (by drawing closed envelopes) divided into two groups.

One group designated as the $\mathrm{N}_{2} \mathrm{O}$ group who were anaesthetized with 40/60 $\mathrm{O}_{2} \mathrm{~N}_{2} \mathrm{O}$ and the other group designated as the AIR group who were anaesthetized with 40/60 and $\mathrm{O}_{2 /}$ air while desfluran (Suprane, Baxter, Puerto Rico, USA) with minimum alveolar concentration of $1 \%$ was included. Anaesthesia was maintained by $2 \mathrm{~L} /$ minute flow; respiration frequency of 12 /minute; tidal volume $8 \mathrm{~m} / \mathrm{kg}$; inspiration/expiration (I/E) ratio of $1: 2$ and end expiratory pressure: $5 \mathrm{mmHg}$ in all patients

$\mathrm{HR}, \mathrm{MBP}$, and $\mathrm{SpO}_{2}$ were recorded 5, 10, 15, 20, $25,30,40,50,60,70,80,90$ minutes before and after intubation and 5 minutes before and after extubation. ETT cuff pressure in both groups were measured and recorded at $5,10,15,20,30,40,60,70,80$ and 90 minutes during intubation and immediately before extubation. In order to avoid tracheal damage, ETT cuff pressure at each measurement time was reduced to the initial level if exceeded $45 \mathrm{~cm} \mathrm{H}_{2} \mathrm{O}$ and air escape sound was controlled over the sternal notch.

At the end of the surgery, both groups were ventilated with $100 \% \mathrm{O}_{2}$ and the inhalation agent was closed. When spontaneous respiration commenced, extubation was implemented after decurarisation. All patients were given $15 \mathrm{mg} / \mathrm{kg}$ paracetamol intravenous for analgesia. In the recovery room, the patients were given nasal $\mathrm{O}_{2}(2 \mathrm{~L} / \mathrm{min})$. One hour and 24 hours post-operation, the patients were evaluated for sore throat and hoarseness.

\section{Statistical Analyses}

Statistical analyses were made using the Number Cruncher Statistical System 2007 and Power Analysis and Sample Size 2008 Statistical Software (Utah, USA) program. Data were evaluated by definitive criteria of the mean, standard deviation, median, frequency, ratio, minimum, 
and maximum. Also for the comparison of the quantitative data on normally distributed variables for two groups, the student's t-test, and for two groups of parameters without normal distribution, the Mann-Whitney $U$ test was used. Qualitative data were compared using Fisher's exact test and the Yates' continuity correction (Yates' correction on the chi-square approximation). Intragroup comparison of parameters with normal distribution was carried out using the paired-samples t-test. Correlation between parameters was estimated by means of the Spearman's correlation analysis. A p value of less than 0.01 and 0.05 was considered statistically significant.

\begin{tabular}{|c|c|c|c|c|}
\hline \multicolumn{5}{|c|}{ Table. Demographic values } \\
\hline \multirow{2}{*}{\multicolumn{2}{|c|}{ Median \pm SD }} & $\mathrm{N}_{2} \mathrm{O}(\mathrm{n}=24)$ & AIR $(n=26)$ & \multirow{2}{*}{ p } \\
\hline & & Median \pm SD & & \\
\hline \multicolumn{2}{|l|}{ Age } & $51.38 \pm 13.33$ & $48.27 \pm 16.89$ & ${ }^{\mathrm{a}} 0.477$ \\
\hline \multicolumn{2}{|l|}{ Height $(\mathrm{cm})$} & $166.67 \pm 6.08$ & $167.62 \pm 7.12$ & ${ }^{a} 0.616$ \\
\hline \multicolumn{2}{|l|}{ Weight (kg) } & $69.17 \pm 10.03$ & $70.58 \pm 9.79$ & ${ }^{\mathrm{a}} 0.617$ \\
\hline \multicolumn{2}{|l|}{ BMI $\left(\mathrm{kg} / \mathrm{m}^{2}\right)$} & $24.88 \pm 3.17$ & $25.11 \pm 3.01$ & ${ }^{\mathrm{a}} 0.791$ \\
\hline \multirow{2}{*}{\multicolumn{2}{|c|}{$\begin{array}{l}\text { Operation time }(\mathrm{min}) \text {; } \\
\text { (median) }\end{array}$}} & $\begin{array}{l}112.29 \pm 62.42 \\
(107.0)\end{array}$ & $\begin{array}{l}96.88 \pm 52.55 \\
(82.5)\end{array}$ & ${ }^{b} 0.386$ \\
\hline & & n (\%) & n (\%) & $\mathbf{p}$ \\
\hline \multirow{2}{*}{ Gender } & Women & $13(54.2 \%)$ & $14(53.8 \%)$ & \multirow{2}{*}{${ }^{`} 1.000$} \\
\hline & Men & $11(45.8 \%)$ & $12(46.2 \%)$ & \\
\hline \multirow{2}{*}{ ASA score } & 1 & $14(58.3 \%)$ & $15(57.7 \%)$ & \multirow{2}{*}{${ }^{c} 1.000$} \\
\hline & 2 & $10(41.7 \%)$ & $11(42.3 \%)$ & \\
\hline \multirow{2}{*}{ Mallampati score } & 1 & $7(29.2 \%)$ & $6(23.1 \%)$ & \multirow{2}{*}{${ }^{\circ} 0.867$} \\
\hline & 2 & $17(70.8 \%)$ & $20(76.9 \%)$ & \\
\hline \multirow{4}{*}{ Tube number } & 7.0 & $6(25.0 \%)$ & $6(23.1 \%)$ & ${ }^{c} 1.000$ \\
\hline & 7.5 & $9(37.5 \%)$ & $10(38.5 \%)$ & ${ }^{c} 1.000$ \\
\hline & 8.0 & $7(29.2 \%)$ & $9(34.6 \%)$ & ${ }^{\circ} 0.913$ \\
\hline & 8.5 & $2(8.3 \%)$ & $1(3.8 \%)$ & ${ }^{d} 0.602$ \\
\hline
\end{tabular}

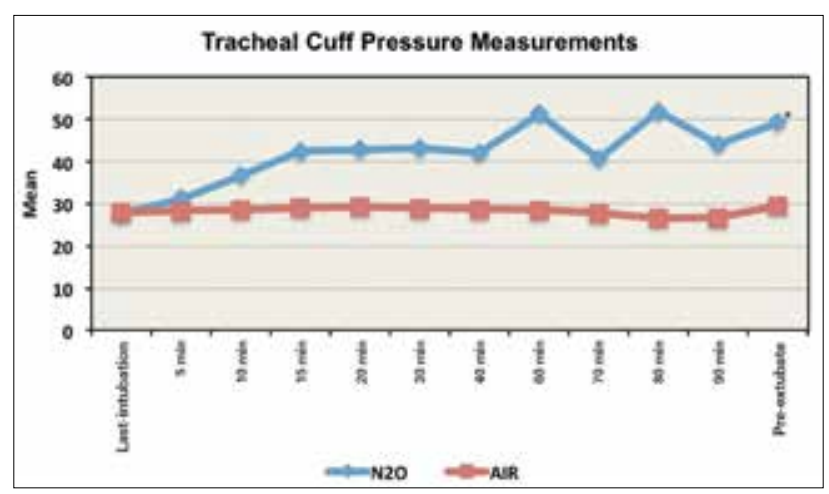

Graphic 1. Tracheal cuff pressure values

\section{Results}

There was no statistically significant difference $(p>0.05)$ in the demographic characteristics, ASA classification, Mallampati scores and the intubation tube numbers between the groups (Table).

Haemodynamic parameters of BP and HR did not differ significantly between the two patient groups.

Cuff pressure values were significantly higher $(p<0.001)$ in the $\mathrm{N}_{2} \mathrm{O}$ group throughout the anaesthesia duration as compared to the AIR group (Graphic 1). Also, a slight but positive correlation $(r=0.281 ; p<0.05)$ was determined between the tube numbers and the cuff pressure after intubation.

When comparing the data on the incidences of sore throat and hoarseness between the two groups, the value for the $\mathrm{N}_{2} \mathrm{O}$ group was found to be significantly higher $(p<0.001)$ than that for group AIR (Graphic 2,3).

\section{Discussion}

Since $\mathrm{N}_{2} \mathrm{O}$ is 35-fold more soluble in blood than $\mathrm{N}_{2}$ gas, during general anaesthesia, it diffuses rapidly into air filled spaces like ETT cuff. The chemical make-up of the material used for ETT also contributes to the degree of $\mathrm{N}_{2} \mathrm{O}$ permeation (2). The high-volume low-pressure ETT

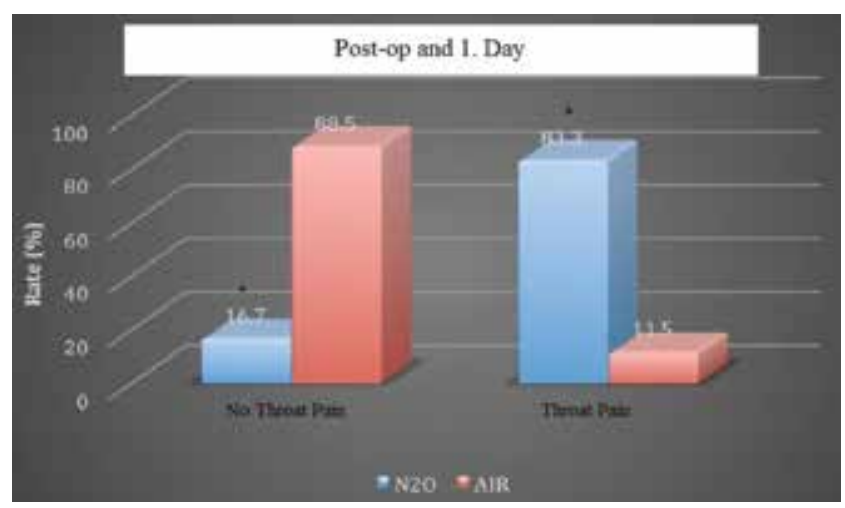

Graphic 2. Postop sore throat incidence,

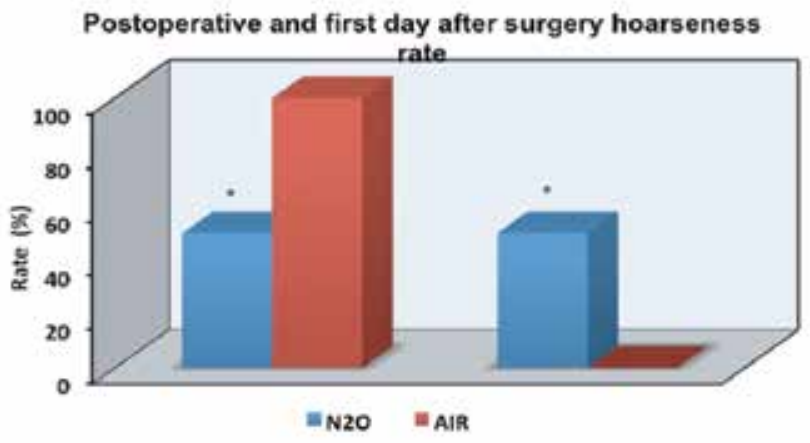

Graphic 3. Postoperative hoarseness rate 
used currently are made of PVC and $\mathrm{N}_{2} \mathrm{O}$ permeability of this material is high (3), although cuffs made of materials containing rubber have even higher permeability $(2,3)$.

During general anaesthesia $\mathrm{N}_{2} \mathrm{O}$ diffusion into the ETT cuff increases the cuff pressure. Studies have estimated that cuff pressure reaches in 1 hour to levels that impair microcirculation. Use of special tubes could extend this time to 210 hours $(5,8)$. At $35 \mathrm{~cm} \mathrm{H}_{2} \mathrm{O}$, cuff pressure partially reduces the mucosal blood flow and total obstruction and ischaemia results at $45 \mathrm{~cm} \mathrm{H}_{2} \mathrm{O}$ within 1530 minutes $(2,9)$. ETT cuff pressure adequacy is judged by the non-quantitative method of palpation, and results in high incidence of errors (2).

After using the cuff balloon palpation method for adjusting EET cuff pressure in the operation rooms of our hospital for long years, use of pressure measuring manometers have been started during the last year for cuff pressure measurement and control during anaesthesia.

In this study, the time-dependent changes that take place during general anaesthesia induced by using $\mathrm{O}_{2} /$ $\mathrm{N}_{2} \mathrm{O}$ gas mixture in the high volume low-pressure ETT cuff and post-operative sore throat and hoarseness were investigated and compared to the corresponding results of general anaesthesia with $\mathrm{O}_{2}$ /air mixture. A previous controlled study on the time-dependent effect of $\mathrm{N}_{2} \mathrm{O}$ on cuff pressure showed no change in cuff pressure in the first 15 minutes of intubation, but significantly higher $(p<0.05)$ values were recorded at 30 minutes in the group anaesthetized with $\mathrm{N}_{2} \mathrm{O}$. Intragroup comparisons on the cuff pressure in the $\mathrm{N}_{2} \mathrm{O}$ anaesthetized group showed a statistically significant increase in the cuff pressure starting at 10 minutes after intubation and reaching significantly high levels exceeding $45 \mathrm{~cm} \mathrm{H}_{2} 0$ at the $45^{\text {th }}$ minute. In this particular study, high-volume low-pressure ETT made from siliconized PVC with a cuff thickness of $0.12 \mathrm{~mm}$ was used (10). Results of a study on $\mathrm{N}_{2} \mathrm{O}$ effect on the pressure in cuffs inflated with air or physiological serum showed continual increase in the air filled cuff pressure reaching levels above $40 \mathrm{~cm} \mathrm{H}_{2} \mathrm{O}$ by 90 minutes (3). Our results have confirmed these reports in that in the $\mathrm{N}_{2} \mathrm{O}$ group, in comparison to the AIR group, the cuff pressure had risen significantly and had reached above $45 \mathrm{~cm} \mathrm{H}_{2} \mathrm{O}$ at the $45^{\text {th }}$ minute after intubation.

The intragroup variation in the rate of increase in cuff pressure can be ascribed to the use of tracheal tubes with differing $\mathrm{N}_{2} \mathrm{O}$ permeability. For example, it has been shown that cuff thickness varied inversely with the cuff $\mathrm{N}_{2} \mathrm{O}$ permeability $(3,9)$. PVC made ETT with a thickness of 0.06 $\mathrm{mm}$ had low $\mathrm{N}_{2} \mathrm{O}$ permeability and high compliance (11). In our study, thickness of the high-volume low-pressure cuffs made of PVC was $0.08 \mathrm{~mm}$.
Checking cuff pressure by palpating the cuff balloon is a non-quantitative method with a high potential of erroneous results (2). Studies have stressed that this is not corrigible by means of training or taking the time for expertise, and that standard manometers should be used instead $(12,13)$. Indeed, it has been shown that manometrically estimated cuff pressures were lower than the estimations made by the expertly palpation of the cuff balloon, which were higher than the expected values (14).

In our study, there was no statistically significant difference in ETT cuff pressure after intubation between the groups. After intubation, the first values of the pressures in the cuffs inflated by the palpation method in the $\mathrm{N}_{2} \mathrm{O}$ group and AIR group were found to be $27.67 \pm 0.76 \mathrm{~cm}$ $\mathrm{H}_{2} \mathrm{O}$ and $27.81 \pm 0.94 \mathrm{~cm} \mathrm{H}_{2} \mathrm{O}$, respectively; these readings are at the upper limit of the ideal cuff pressure range. The lowest and the highest estimated limits were $17 \mathrm{~cm} \mathrm{H}_{2} \mathrm{O}$ and $52 \mathrm{~cm} \mathrm{H}_{2} \mathrm{O}$, respectively. In addition, there was a slight positive correlation between these pressure levels and the ETT numbers $(r=0.281 ; p<0.05)$, which however, was not observed in the following estimations on the increasing cuff pressure with time after intubation.

There are a number of reasons for sore throat experienced after ETT intubation, including not using lubricants during intubation, drying of the mucosal lining of the mouth and the glottis, pressure on the arytenoid cartilages and elevated cuff pressure (1). There are studies reporting the existence and the absence of a correlation between sore throat and ETT cuff pressure $(1,15,16)$. Tracheal tube dimensions and design are also important causal factors. Routine endotracheal intubation for elective surgery can result in pathological changes, traumas and nerve damage (17). Observation of no differences of sore throat incidence in groups anaesthetized with or without $\mathrm{N}_{2} \mathrm{O}$ use was attributed to the normalization of cuff pressure when it reached $45 \mathrm{~cm} \mathrm{H}_{2} \mathrm{O}$ during the anaesthesia in a study (10). The authors attributed this situation to the fact that they fixed blood pressure at 45 $\mathrm{cm} \mathrm{H}_{2} \mathrm{O}$ and used nasogastric tube in whole abdominal cases.

A study on 167 patients intubated for short periods of time, 54 (32\%) complained of hoarseness post surgery, and the symptoms completely disappeared within 5 days (18). In two patients with persistent hoarseness for 54 and 99 days, vocal cord granulomas were detected. In our study, analysis of the incidence of hoarseness and sore throat 1 and 24 hours after extubation showed that $50 \%$ of patients had hoarseness in the $\mathrm{N}_{2} \mathrm{O}$ group while no patient had hoarseness in the AIR group; $70.83 \%$ of patients (17 of 24) in the $\mathrm{N}_{2} \mathrm{O}$ group and $11.5 \%$ of patients ( 3 of 26) in the AIR group had sore throat. 


\section{Conclusion}

When high-volume low-pressure ETTS made of PVC with a cuff thickness of $0.08 \mathrm{~mm}$ were used in anaesthesia with $\mathrm{N}_{2} \mathrm{O}$ inclusion, we observed, that the cuff pressures were high enough to impair the tracheal mucosa within 40 minutes of intubation. Hence, it is obvious that $\mathrm{N}_{2} \mathrm{O}$ diffusion into the ETT cuff will increase the cuff pressure to levels that will cause tracheal morbidity. It has also been shown in this study that palpation method of adjusting cuff pressure results in wrong pressures, higher than expected. Additionally, as the tube dimensions increase, there is a slight but definite possibility of increased risk of inflating the cuff with wrong high pressure. We believe that the best approach in anaesthesia practice to prevent or minimize complications arising from tracheal mucosal damage caused by elevated ETT cuff pressure is to monitor the cuff pressure regularly during anaesthesia and make readjustments to normal levels if necessary.

\section{Ethics}

Ethics Committee Aprovel: Haseki Training and Research Hospital aprovel ID: 43, 11.10.2013. Informed Consent: It was taken.

Peer-review: Externally peer-reviewed.

\section{Authorship Contribution}

Surgical and Medical Practices: Özlem Koşar, Öznur Şen, Gamze Mısırlıoğlu. Consept: Özlem Koşar, Öznur Şen. Design: Öznur Şen, Özlem Koşar, Mehmet Toptaş, Nurdan Aydın. Data Collection or Practices: Özlem Koşar, Öznur Şen, Gamze Mısırlıoğlu, Nurdan Aydın, Emel Koçer Gür, Tarık Umutoğlu. Analysis or Interpretation: Özlem Koşar, Öznur Şen, Tarık Umutoğlu. Literature Search: Özlem Koşar, Öznur Şen, Nurdan Aydın. Writing: Özlem Koşar, Öznur Şen.

Conflict of Interest: No conflict of interest was declared by the authors.

Financial Disclosure: The authors declared that this study received no financial support.

\section{References}

1. Kayhan Zeynep. Klinik Anestezi. Endotrakeal Entübasyon. 3. Baskı. Logos Yayıncılık, İstanbul; 2004.

2. Somri M, Fradis M, Malatskey S, Vaida S, Gaitini L. Simple online endotracheal cuff pressure relief valve. Ann Otol Rhinol Laryngol 2002;111:190-4.

3. Combes $X$, Schauvliege F, Peyrouset $O$, et al. Intracuff pressure and tracheal morbidity: influence of filling with saline during nitrous oxide anesthesia. Anesthesiology 2001;95:1120-4.
4. Stewart SL, Secrest JA, Norwood BR, Zachary R. A comparasion of endotracheal tube cuff pressures using estimation techniques and direct intracuff measurement. AANA J 2003;71:443-7.

5. Benneth $M H$, Isert PR, Cumming RG. Postoperative sore throat and hoarseness following tracheal entubation using air or saline to inflate the cuff-a randomized controlled trial. Anaesth Intensive Care 2000;28:408-13.

6. Beebe DS. Complications of tracheal entubation. Semin Anesth Perioperat Med Pain 2001;20:166-72.

7. Seegobin RD, Hasselt GL. Endotracheal cuff pressure and tracheal mucosal blood flow: Endoscopic study of effects of four large volume cuffs. Br Med J (Clin Res Ed) 1984;288:9658.

8. Karasawa F, Mori T, Okuda T, Satoh T. Profile soft-seal cuff, a new endotracheal tube, effectively inhibits an increase in the cuff pressure through high compliance rather than low diffusion of nitrous oxide. Anesth Analg 2001;92:140-4.

9. al-Shaikh $B$, Jones $M$, Baldwin $F$. Evaluation of pressure changes in a new design tracheal tube cuff, the Portex Soft Seal, during nitrous oxide anaesthesia. $\mathrm{Br} J$ Anaesth 1999;83:805-8.

10. Altunkaya H, Çıtır S, Özkoçak I, et al. Azotprotoksitin Zamana Göre Endotrakeal Kaf Basıncına Etkisi. Türk Anest Rean Der Dergisi 2004;32:362-6.

11. AlShaikh B. New cuff design prevents N2O diffusion. Anesth Analg 2000;91:10-2.

12. Ayoğlu H, Yurtlu BS, Hancı V, et al. Anestezi çalışanlarınca pilot bolanun palpasyonu ile ayarlanan endotrakeal tüp kaf basınçlarının değerlendirilmesi. Türkiye Klinikleri J Anest Reanm 2009; 7:88-92.

13. Al-Metwalli RR, Al-Ghamdi AA, Mowafi HA, Sadek S, Abdulshafi $M$, Mousa WF. Is sealing cuff pressure easy, reliable and safe tecnigue for endotracheal tube cuff inflation?: A comparative study. Saudi J Anaesth 2011;5:185-9.

14. Liu J, Zhang X, Gong W, et al. Correlations between controlled endotracheal tube cuff pressure and postprocedural complications: a multicenter study. Anesth Analg 2010;111:1133-7.

15. Atkinson RS, Rusman GB, Davies NJH. Lee's Synopsis of Anesthesia. 11th ed. Oxford: Butterworth- Heinemann; 1993. p. 217-38.

16. Kayhan Z. Anesteziyolojinin Tarihsel Gelişimi ve Geleceği. Klinik Anestezi. 3.baskı. İstanbul: Logos yayıncılık; 2004.

17. McHardy FE, Chung F. Postoperative sore throat: cause, prevention and treatment. Anaesthesia 1999;54:444-53.

18. Jones MW, Catling S, Evans E, Green DH, Green JR. Hoarseness after tracheal intubation. Anaesthesia 1992;47:213-6. 